\title{
Kualitas Pelayanan Becak Wisata pada Wisatawan Kapal Pesiar di Kota Probolinggo
}

\author{
Abul Haris Suryo Negoro ${ }^{1}$, Pandu Satriya Hutama ${ }^{2}$
}

12Jurusan Ilmu Administrasi, Universitas Jember, Indonesia

\begin{tabular}{|c|c|}
\hline & ABSTRACT \\
\hline $\begin{array}{l}\text { Keywords: } \\
\text { Services, } \\
\text { Tourist Pedi Cap, } \\
\text { Asociation, } \\
\text { Tourist, } \\
\text { Cruise Ship }\end{array}$ & $\begin{array}{l}\text { Abstrak: The Probolinggo City's tourist pedi cap has shown its own strategic } \\
\text { role on service of cruise ship tourists. The quality service of tourist has hold an } \\
\text { important part in gaining promotion and developing of tourism in Probolinggo } \\
\text { City. However, it remains some problems, such as low quality of services } \\
\text { offerded by pedi cap drivers as part of tourism interesting product, and the } \\
\text { inconsistency of organizational function system acted as gaining the quality of } \\
\text { tourist services by pedi cap driver. It aims to improve the quality of services by } \\
\text { pedi cap driver as part of main tourist transportation service, and to revitalize } \\
\text { the association's function of Becak Bestari to improve the quality of tourist } \\
\text { service. It uses the descriptive qualitative methode. The result is remain some } \\
\text { aspects, such as the necessary on making of Standard Operational Procedur } \\
\text { (SOP) specifically for the tourist cruise ship service, and revitalize the } \\
\text { organizational function system of Becak Bestari of Probolinggo City. The } \\
\text { conclusions are the SOP for tourist cruise ship service is become basic service for } \\
\text { the tourists, and the new organizational system effort to adopt the developing } \\
\text { of needs on tourist services. }\end{array}$ \\
\hline $\begin{array}{l}\text { Kata Kunci: } \\
\text { Pelayanan, } \\
\text { Becak Wisata, } \\
\text { Asosiasi, } \\
\text { Wisatawan, } \\
\text { Kapal Pesiar }\end{array}$ & $\begin{array}{l}\text { Abstrak: Becak wisata Kota Probolinggo telah menunjukan peran strategisnya } \\
\text { dalam pelayanan wisatawan kapal pesiar. Kualitas pelayanan becak wisata } \\
\text { menjadi bagian penting peningkatan promosi dan pengembangan pariwisata di } \\
\text { Kota Probolinggo. Beberapa permasalahan yang muncul, yaitu rendahnya } \\
\text { kualitas pelayanan pengemudi becak wisata yang masih belum menjadi sebuah } \\
\text { produk wisata menarik, dan ketidakkonsistenan fungsi kelembagaan asosiasi } \\
\text { sebagai fasilitator peningkatan kualitas pelayanan wisatawan kepada para } \\
\text { anggotanya. Tujuannya untuk meningkatkan pelayanan becak wisata sebagai } \\
\text { moda transportasi unggulan serta merevitalisasi fungsi kelembagaan Asosiasi } \\
\text { Becak Bestari dalam peningkatan kualitas pelayanan wisatawan. Metode yang } \\
\text { dipergunakan yaitu menggunakan metode penelitian deskriptif kualitatif. } \\
\text { Menghasilkan beberapa aspek, yaitu rumusan Standar Operasional Prosedur } \\
\text { (SOP) khusus pelayanan becak wisata untuk wisatawan kapal pesiar, serta } \\
\text { menyusun fungsi sistem kelembagaan Becak Bestari Kota Probolinggo. } \\
\text { Kesimpulan bahwa SOP khusus pelayanan wisatawan kapal pesiar menjadi } \\
\text { panduan pelayanan dasar kepada wisatawan, serta system kelembagaan baru } \\
\text { mampu mengadopsi perkembangan kebutuhan terhadap pelayanan kepada } \\
\text { wisatawan. }\end{array}$ \\
\hline
\end{tabular}

Correspondance address:

E-mail: pandu.fisip@unej.ac.id (Pandu Satriya hutama)

\section{Pendahuluan}

Indonesia yang terkenal dengan sumber kekayaan alam yang melimpah dan keindahan alamnya. Berkembanganya Indonesia sebagai salah satu destinasi wisata di Asia memunculkan potensi 
perekonomian yang berkembang pula. Pariwisata Indonesia yang mengeliat dihadapkan pada beberapa permasalahan yang harus diselesaikan oleh pemerintah pusat dan daerah. Hal yang perlu diselesaikan terkait kebijakan, infrastruktur, dan kompetensi sumberdaya manusia. Dalam kajian ini, pembahasan yang dilakukan berkaitan permasalahan yang sering berkembang, terkait sarana transportasi yang belum memadai. Kontribusi signifikan transportasi sebagai media transit yang yang substansial dalam mempermudah proses mobilisasi dan perpindahan ke berbagai destinasi wisata. Menurut data Kementerian Pariwisata RI (2017), minat wisatawan terhadap sarana transportasi lokal di Indonesia mencapai $8.93 \%$ di tahun 2016. Moda transportasi dalam proses mobilitas pengunjung destinasi wisata menjadi utama karena berkaitan kenyamanan dan media untuk mencapai tujuan wisata. Pemenuhan moda transportasi dalam sektor pariwisata harus didukung oleh kebijakan negara baik pusat dan daerah. Pentingnya kebijakan publik sebagai kepastian hukum dalam keberlanjutan pariwisata di masa depan.

Perkembangan dunia yang dinamis menuju arah globalisasi sehingga memunculkan kompetisi antarnegara dalam mewujudkan gagasan, ide, dan inovasi dalam segala sektor. Tantangan globalisasi ini mengarah pada kesiapan negara dalam mempersiapkan antisipasi hal tersebut. Negara perlu merespon tantangan globalisasi dengan menetapkan strategi yang memiliki tujuan dan manfaat ganda. Strategi yang harus dilakukan berupa sharing of power, distribution of income, dan kemandirian sistem manajemen (Azhari, 2019: 90). Respon ini tidak hanya dilakukan oleh pemerintah pusat tetapi juga harus dilakukan oleh pemerintah daerah sehingga ada kesinambungan dan terintegrasi dalam mempersiapkan sektor pariwisata yang mempunyai nilai jual tinggi bagi para wisatawan. Hal tersebut bisa dilakukan bila pembagian kekuasan, pendistribusian pendapatan, dan pengelolaan manajemen antarapusat dan daerah bisa berkordinasi dan mengurangi adanya ego sektoral antarlembaga negara untuk terciptanya pariwisata ilndonesia yang mendunia.

Strategi dalam penyediaan media transportasi yang memadai, juga diperlukan adanya sumber informasi yang lengkap berkaitan destinasi wisata. Dengan menjadikan strategi penyediaan informasi sebagai dasar dalam pengambilan keputusan individu dapat mempengaruhi pengembangan pariwisata dan aktivitas keseharian dalam suatu destinasi yang dipilih (Ricthie dan Crouch, 2003: 148). Aspek ketersediaan dan kebenaran informasi mampu membangun persepsi positif calon wisatawan dalam penentuan moda transportasi yang diinginkan. Di tengah tren perkembangan aspek transportasi yang berbasis teknologi, berkembang upaya memberikan kenyamanan dan mempercepat proses mobilisasi orang. Kecepatan dan kenyamanan dalam proses pemindahan, sangat dibutuhkan dan menjadi unsur utama sebagai wujud identitas masyarakat modern. Perkembangan pola transportasi modern tidak dapat dihindari, dan akan terus mengalami perubahan secara cepat dan massal. Berbagai moda transportasi modern akan menjadi pilihan alternatif strategis meningkatkan perkembangan pariwisata.

Namun demikian, derasnya perkembangan moda transportasi modern, berpengaruh terhadap pengembangan moda transportasi tradisional. Becak sebagai salah satu moda transportasi tradisional yang masih tetap eksis, namun sangat lambat dalam perkembangan fisiknya. Becak bermanfaat dalam proses pemindahan orang, namun juga sebagai sarana pemindahan barang yang efektif dan murah. Dalam perkembangannya, becak semakin terdistorsi seiring dengan peningkatan laju modernisasi dibidang transportasi, menjadi kebutuhan dan bagian dari gaya hidup serta menjadi ekspektasi masyarakat. Eksistensi transportasi tradisional hanya terlihat pada aspek bentuk dan model fisik becak. Namun becak memiliki sistem pelayanan yang unik dan berpotensi sebagai produk dengan nilai jual tinggi.

Becak sesuai fungsinya dapat dikategorikan menjadi dua, yaitu becak biasa dan becak wisata. Becak biasa diperuntukan untuk mengangkut orang dan barang, sedangkan becak wisata diperuntukan dalam mengangkut wisatawan. Secara fisik tidak ada perbedaan signifikan diantara kedua jenis becak, namun unsur pelayanan dan pasar sasaran menjadi unsur pembeda. Segmen pasar becak biasa adalah orang dan barang, sedangkan becak wisata lebih difokuskan pada wisatawan dengan seperangkat pelayanannya. Aspek pelayanan jasa pengemudi becak wisata memiliki posisi tawar yang sangat tinggi, selain aspek keamanan dan kenyamanan fasilitas. Kenyamanan dan keamanan moda transportasi bagi wisatawan menjadi inti sebuah perjalanan wisata (Gallimore, 2011). Becak wisata menjadi momentum berupa icon pariwisata di Probolinggo yang layak jual bagi wisatawan yang menaiki kapal pesiar. 
Keunikan becak wisata akan memberikan kesan mendalam bagi para wisatawan. Pelayanan kepada wisatawan kapal pesiar yang membutuhkan pelayanan prima berupa keramahan (senyum dan sapa), sampai dengan kemampuan memberikan informasi dengan baik. Selain itu, becak memegang peranan penting terhadap pengurangan dampak lingkungan, memunculkan pola kebijakan terkait aspek penggunaan sarana transportasi yang ramah lingkungan dan rendah emisi (Middleton dan Hawkins, 1998).

Merujuk data wawancara yang dilakukan peneliti, bahwa Paguyuban Becak Bestari Kota Probolinggo sebagai satu-satunya lembaga nirlaba yang membawahi para pengendara becak sekota dan kabupaten Probolinggo. Paguyuban Becak Bestari memiliki jumlah anggota mencapai 4.525 pengendara becak di tahun 2013, memiliki potensi yang luar biasa. Mengutip dari data yang dikeluarkan oleh Dinas Kebudayaan dan Pariwisata Kota Probolinggo (2018) bahwa becak wisata menjadi front liner pelayanan kepada wisatawan kapal pesiar sejak tahun 2011. Dengan memasukan salah satu pelayanan jasa transportasi tradisional becak wisata ke dalam paket wisatawan kapal pesiar city tour kota Probolinggo. Menstimulus peran pengendara becak wisata memberikan kualitas pelayanan prima, dalam rangka membangun citra wisata kota Probolinggo. Pelayanan ini berlangsung cukup lama dan masih memunculkan beberapa permasalahan yang belum terselesaikan. Masih belum optimalnya pelayanan kepada wisatawan, berkaitan dengan kemampuan dan profesional pengemudi becak tersebut. Serta sarana transportasi becak wisata yang minim fasilitas dan belum mampu menjadi sebuah produk pelayanan khas dan unik. Serta lemahnya fungsi kelembagaan pemerintah daerah sebagai fasilitator pembinaan pelayanan wisatawan kepada pengemudi becak.

Berbagai permasalahan yang masih dihadapi oleh Paguyuban Becak Bestari, memberikan andil yang kurang optimal dalam mendukung pengembangan dan promosi pariwisata di kota Probolinggo. Disisi lain, kebutuhan terhadap pelayanan jasa transportasi becak wisata, akan terus berkembang setiap tahunnya. Seiring dengan intensitas kedatangan kapal pesiar ke kota Probolinggo yang terus berkembang setiap tahunnya. Tujuannya yaitu berupaya meningkatkan pelayanan becak wisata sebagai moda transportasi unggulan, menjadikan becak wisata sebagai produk pariwisata khas kota Probolinggo serta meningkatkan fungsi kelembagaan dalam peningkatan kualitas pelayanan wisata.

\section{Metode}

Sistem pengumpulan data, yaitu dengan menggunakan metode pengamatan dan wawancara langsung. Pengamatan lapangan dilakukan pada kunjungan kapal pesiar ke kota Probolinggo yang berlangsung selama 5 jam setiap bersandar pada Pelabuhan Tanjung Tembaga. Sedangkan proses wawancara, dilaksanakan ke pengurus (ketua dan sekretaris) Paguyuban Becak Bestari kota Probolinggo, narasumber dari wisatawan kapal pesiar dan pengemudi becak wisata. Instrumen pokok dalam penelitian kualitatif adalah peneliti sendiri. Dalam penelitian ini digunakan analisa data secara interaktif sebagaimana dinyatakan oleh Miles dan Huberman (1992) yang terdiri dari reduksi data, sajian data, dan penarikan kesimpulan.

\section{Hasil dan Pembahasan}

Kota Probolinggo memiliki posisi yang strategis sebagai pintu masuk utama menuju kawasan wisata Bromo Tengger Semeru, penghubung jalur laut, serta sebagai pusat bongkar muat barang melalui pintu masuk pelabuhan. Menjadikan kota Probolinggo sebagai pusat penyebaran wisatawan ke berbagai destinasi wisata di Kota dan Kabupaten Probolinggo. Merujuk dari data yang diperoleh dari Dinas Kebudayaan dan Pariwisata tahun 2018 menunjukan bahwa jumlah wisatawan mancanegara yang berkunjung ke kota Probolinggo mencapai 3.648 orang di tahun 2017 (Dinas Kebudayaan dan Pariwisata kota Probolinggo, 2018). Salah satu segmen unggulan wisatawan mancanegara ke kota Probolinggo berasal dari wisatawan kapal pesiar, yang masuk melalui Pelabuhan Tanjung Tembaga. Sedangkan data kunjungan wisatawan kapal pesiar melalui Pelabuhan Tanjung 
Tembaga di tahun 2017, mencapai 5.024 orang. Dengan tujuan utama untuk berkunjung ke kawasan wisata Gunung Bromo dan City Tour Kota Probolinggo.

Tabel 1. Jumlah Wisatawan Mancanegara melalui Pelabuhan Tanjung Tembaga Kota Probolinggo Tahun 2014 - 2017

\begin{tabular}{lcccc}
\hline \multirow{2}{*}{ Bulan } & \multicolumn{5}{c}{ Jumlah Wisatawan Mancanegara pada Tahun } \\
\cline { 2 - 5 } & $\mathbf{2 0 1 4}$ & $\mathbf{2 0 1 5}$ & $\mathbf{2 0 1 6}$ & $\mathbf{2 0 1 7}$ \\
\hline Januari & 908 & 52 & 851 & 337 \\
\hline Februari & 170 & - & 898 & - \\
\hline Maret & - & 232 & 838 & 483 \\
\hline April & - & 24 & - & 1.130 \\
\hline Mei & - & 522 & 850 & 206 \\
\hline Juni & - & - & 1.985 & - \\
\hline Juli & - & - & 2.203 & 1.080 \\
\hline Agustus & - & - & 912 & 52 \\
\hline September & 212 & - & - & 1.305 \\
\hline Oktober & - & - & 156 & 170 \\
\hline Nopember & - & 703 & 1.181 & 261 \\
\hline Desember & - & 944 & 1.052 & - \\
\hline TOTAL & 1.290 & 2.477 & 10.926 & 5.024 \\
\hline
\end{tabular}

Fluktuasi tingkat kedatangan kapal pesiar, didasarkan pada antusiasme operator-operator kepal pesiar berkunjung ke kota Probolinggo. Tinggi intensitas kunjungan kapal pesiar, memberikan dampak ekonomi bagi masyarakat dan para pelaku usaha pariwisata. Khususnya bagi masyarakat yang terlibat langsung dalam memberikan pelayanan wisatawan kapal pesiar. Kualitas pelayanan pengemudi becak wisata memegang peran penting, sebagai media promosi destinasi wisata paling efektif. Kualitas terbagi menjadi kelengkapan-kelengkapan produk dan menghilangkan dari berbagai bentuk kelemahan (Kotler, 1996: 354). Potensi ini membuka peluang bagi anggota masyarakat di kota Probolinggo dalam memperoleh pendapatan lebih optimal, melalui media becak wisata.

Sejak tahun 2011, paguyuban becak wisata dengan nama Paguyuban Becak Bestari kota Probolinggo telah terlibat langsung dalam pelayanan wisatawan kapal pesiar. Asosiasi resmi ini dibentuk dan difasilitasi oleh Badan Perencanaan Pembangunan Daerah (Bappeda) kota Probolinggo pada tahun 2011. Paguyuban becak wisata dibentuk bertujuan untuk meningkatkan potensi sumberdaya manusia dan kesempatan pada peningkatan perekonomian masyarakat. Mengutip dari hasil wawancara dengan paguyuban becak wisata, paguyuban ini dibentuk dengan tujuan mempererat silahturahmi antara anggota aktif dan non anggota paguyuban untuk lebih berkarya, memberdayakan potensi semua aset organisasi untuk kesejahteraan masyarakat. Serta memberikan peluang berusaha seluas-luasnya pada sebuah wadah organisasi dalam konteks pemberdayaan masyarakat.

Merujuk data penelitian yang diperoleh dan diolah, menunjukkan bahwa sistem keanggotaan Paguyuban Becak Bestari kota Probolinggo dibagi ke dalam lima kecamatan dan dua puluh sembilan kelurahan, yaitu kecamatan Mayangan sebanyak 1.151 pengendara becak, kecamatan Kanigaran sebanyak 1.150 pengendara becak, kecamatan Kedopok sebanyak 952 pengendara becak, kecamatan Wonoasih sebanyak 735 pengendara becak, dan kecamatan Kademangan sebanyak 536 pengendara becak. Pada masing-masing kecamatan memiliki satu koordinator dan satu koordinator pada tingkat kelurahan.

Namun demikian, tidak semua anggota Paguyuban Becak Bestari kota Probolinggo menjadi bagian dari anggota becak wisata. Membangkitkan rasa bangga anggota paguyuban, sebagai moda transportasi unggulan para wisatawan kapal pesiar. Pertimbangan utama pada aspek kualitas pelayanan jasa khusus pariwisata. Becak wisata memiliki keunggulan dalam aspek kualitas ruang/spasial, kualitas produk sendiri dan kualitas hubungan. Meskipun dalam aspek kualitas pilihan, 
becak wisata masih belum memiliki keberagaman jasa pelayanan lainnya selain hanya sarana transportasi.

Pemerintah daerah yang diwakili oleh Badan Perencanaan Pembangunan Daerah kota Probolinggo menginisiasi pelayanan publik berbasis pariwisata melalui becak wisata. Bentuk pelayanan publik tersebut untuk meningkatkan potensi pasar pariwisata dan pemberdayaan masyarakat kota Probolinggo. Pemenuhan kebutuhan akan pelayanan publik dalam konteks becak wisata memerlukan adanya standar pelayanan yang cukup. Menurut Kholiq (2019), bahwa standar pelayanan berisi tentang hal-hal yang berkaitan dengan visi, misi, prosedur pelayanan, penawaran pelayanan, dan pengawasan yang berorientasi mutu. Standar pelayanan ini dapat menjadi panduan bagi para pengelola becak wisata untuk menerapkan pelayanan publik berbasis pariwisata dengan prima. Standar pelayanan ini juga menjadi aturan main dalam mengatasi permasalahan becak wisata baik dalam pengelolaan maupun dengan penggunanya. Pengelolaan becak wisata harus berakar pada kultur budaya khas Kota Probolinggo. Beberapa permasalahan yang berkembang dalam pengelolaan becak wisata, terkait rumusan Standar Operasional Prosedur (SOP) khusus Pelayanan Becak Wisata untuk Wisatawan Kapal Pesiar, Pendesainan Ulang Becak Wisata Khas kota Probolinggo serta Menyusun Sistem Kelembagaan Becak Bestari kota Probolinggo. Upaya-upaya tersebut bertujuan mengadopsi perkembangan kebutuhan terhadap pelayanan kepada wisatawan asing.

Terdapat sistem penilaian internal dari paguyuban dalam menjaga kualitas pelayanan kepada para anggotanya. Indikator penilaian internal paguyuban menjadikan pengendara becak harus mematuhi standar pelayanan wisatawan kapal pesiar, yaitu aspek kondisi fisik kelayakan becak, kostum pengendara becak, dan aspek keramahan dalam pelayanan. Becak wisata harus memiliki standar kelayakan tertentu, yang mencakup keseluruhan kondisi fisik becak dengan fungsi-fungsi keselamatannya. Paguyuban becak wisata memiliki kostum khusus sebagai identitas khusus, berupa kaos merah dan putih dengan celana hitam dan udeng. Sedangkan aspek keramahan dilihat dari kemampuan dalam tata cara pengeendara becak wisata dalam melayani, menyapa dan menjaga wisatawan selama dalam perjalanan.

Wisatawan kapal pesiar datang ke kota Probolinggo mempunyai tujuan khusus, dengan aktivitas city tour kota Probolinggo berdurasi kunjungan selama lima jam. Sedangkan durasi city tour menggunakan becak wisata mencapai dua jam, sedangkan total durasi kunjungan ke destinasi wisata mencapai tiga jam. Sesuai dengan maksud dan tujuan kedatangan dan aktivitas wisatawan yang hanya bersenang-senang (leisure). Kebijakan dalam jasa pelayanan leisure, yaitu menyediakan berbagai peluang, dalam aktivitas bersenang-senang untuk memenuhi berbagai kebutuhan dari seluruh anggota masyarakat (Gold, 1980). Membuka peluang besar becak wisata sebagai alat transportasi dalam rangka memenuhi kebutuhan wisatawan kapal pesiar untuk tujuan leisure.

Membangun intensitas interaksi antara pengendara becak wisata dengan wisatawan kapal pesiar, dibutuhkan pelayanan yang berkualitas dari seluruh aspek. Mengutip dari pendapat Fandeli (1995) bahwa ada dua faktor yang mendasari wisatawan melakukan kunjungan wisata pada suatu tempat yaitu: seseorang melakukan perjalanan wisata karena ingin menenangkan pikiran dan terlepas dari kegiatan sehari-hari yang penuh dengan kesibukan dan seseorang datang pada destinasi wisata karena keunikan, kemasyuran akan objek dan atraksi wisata yang akan dikunjungi. Peran pemerintah daerah, swasta dan masyarakat sangat diperlukan dalam mewujudkan kemandirian dan keberlanjutan becak wisata yang terus menarik antusiasme wisatawan dan operator-operator kapal pesiar berkunjung ke Kota Probolinggo. Motivasi dan tujuan wisatawan ini bisa menjadi pemicu bagi pengelola becak wisata untuk meningkatkan kualitas pelayanan wisatanya.

Beberapa permasalahan pelayanan yang berkembang pada becak wisata kota Probolinggo, yaitu perbedaan antara harapan wisatawan dan persepsi mereka terhadap kualitas pelayanan yang diberikan. Khususnya dalam pelayanan fisik becak wisata yang masih belum memenuhi standar, minim kemampuan berbahasa asing serta lemahnya aspek keramahan pelayanan kepada wisatawan. Solusi yang dilakukan untuk memberikan pelayanan yang berkualitas dengan cara memahami keinginan pelanggan dan persepsi pelanggan dengan penilaian baik.

Parasuraman, Zeithaml dan Berry (1985) mengemukakan secara singkat tentang mengukur kualitas sebuah pelayanan. Dengan memodifikasi sesuai perkembangan dan adaptasi dapat 
dikategorikan berupa: (1) tingkat kecepatan dan ketepatan pelayanan; (2) tingkat keandalan berkaitan kemampuan kinerja organisasi; dan (3) perilaku pelayanan aparatur dalam kompetensi, keramahan dan keadilan dalam pelaksanaan pelayanan. Perubahan cara berpikir para pengendara becak diperlukan, dalam rangka peningkatan kapasitas dan kualitas pelayanan. Diperlukan pelatihan dan sosialisasi yang berkesinambungan dalam membentuk karakter pengendara becak yang profesional. Semakin baik kualitas pelayanan yang diberikan berkorelasi erat dengan peningkatan perolehan pendapatannya, baik sesuai dengan porsinya maupun berbagai insentif yang dimungkinkan untuk diberikan oleh wisatawan. Peluang terhadap eksistensi moda transportasi tradisional ditengah perkembangan masyarakat modern akan tetap terbuka seiring dengan laju permintaan.

Pemilihan moda transportasi tradisional berupa becak oleh wisatawan kapal pesiar, dipengaruhi oleh lima dimensi, yaitu aspek fungsional, estetika/emosional, sosial/organisasional, situasional dan keinginan untuk mencoba hal baru (Mill dan Morrison, 1992: 208). Dimensi tersebut memiliki keterkaitan erat dengan kualitas pelayanan becak wisata. Pelayanan dan menaiki becak wisata menjadi pengalaman baru dan sensasi tersendiri untuk dicoba bagi para wisatawan kapal pesiar. City tour dengan menaiki becak wisata, yaitu sebuah kendaraan roda tiga yang dikemudikan oleh seorang pengemudi, sebuah opsi untuk tetap menjangkau seluruh area dalam waktu singkat (Hee, 2017: 105). Paguyuban Becak Bestari Kota Probolinggo yang menjadi moda transportasi utama kegiatan city tour Kota Probolinggo, "Probolinggo Highlights". Paguyuban Becak Bestari kota Probolinggo sebagai satusatunya paguyuban becak wisata, sangat berpeluang untuk terus menjadi moda transportasi khas wisatawan yang berkunjung ke kota Probolinggo.

Pelayanan prima becak wisata akan tercipta dengan mudah apabila kemampuan komunikasi berbahasa asing bisa menjadi kunci kualitas pelayanan pariwisata. Disisi lain, realitas yang muncul di lapangan menunjukkan bahwa hanya $5 \%$ anggota paguyupan becak wisata yang memiliki kemampuan berbahasa Inggris. Minimnya kemampuan anggota dalam berbahasa asing dipengaruhi oleh tingkat pendidikan, yang kebanyakan adalah berpendidikan sekolah dasar. Namun demikian, peran komunikasi dapat berjalan secara alamiah, terjalin melalui aspek keramahan, keberanian dan bahasa isyarat. Sedangkan aspek komunikasi antara wisatawan kapal pesiar dengan pengemudi becak wisata, difasilitasi oleh pemandu wisata yang mengiringi setiap rombongan. Saling pengertian menjadi kunci sukses pelayanan para pengemudi becak wisata.

Meskipun segmentasi unggulan Paguyuban Becak Bestari kota Probolinggo, yaitu wisatawan kapal pesiar. Namun dalam strategi pemasaran wisata, tidak hanya untuk kalangan wisatawan tertentu saja tetapi semua wisatawan yang datang ke kota Probolinggo. Perlunya standar operasional prosedur (SOP) pelayanan becak wisata yang khusus menangani wisatawan kapal pesiar. Dalam standar pelayanan prosedur diperlukan klausul pentingnya aspek keramahan, peningkatan kualitas fisik semangat untuk melayani dan menjaga wisatawan asing selama dalam perjalanan sehingga aspek kemampuan berbahasa asing bagi para pengendara becak wisata tidak mutlak untuk diperlukan dengan berpedoman pada tugas utama kepemanduan dilakukan oleh pemandu wisata yang berfungsi sebagai fasilitator.

Becak wisata saat ini dan di masa depan diproyeksikan akan terus berkembang apabila ada upaya strategis peningkatan kualitas pelayanan. Hal ini dilakukan untuk mempermudah pengambil kebijakan dalam memberikan rekomendasi dan dukungan kebijakan berkaitan pelayanan becak wisata. Pengembangan sistem monitoring dan pendataan wisatawan nusantara untuk mendukung dalam pengambilan keputusan oleh instansi terkait (Kementerian Pariwisata RI, 2002). Rumusan bersama SOP dan pendesainan ulang becak wisata kota Probolinggo sangat diperlukan, khususnya dalam upaya menyesuaikan dengan kebutuhan pelayanan wisatawan kapal pesiar. Masing-masing moda transportasi memiliki keunggulan, dilihat dari kecepatan, kenyamanan dan biaya (Burton, 1995). Pendesainan ulang tidak dalam hal ukuran tempat duduk, namun mempertimbangkan aspek keamanan, keunikan atau kekhasan dan tingkat kenyamanan pengguna. Ukuran tempat duduk becak wisata harus menyesuaikan dengan kebutuhan dan ukuran wisatawan asing. Diharapkan wisatawan dapat lebih nyaman duduk dan tidak berdesak-desakan (apabila pengguna becak wisata lebih dari dua orang). Kekhasan bentuk becak wisata sangat diperlukan, sesuai dengan kultur budaya khas 
Pendhalungan Kota Probolinggo. Pendesainan ulang becak wisata diharapkan menjadi identitas dan atraksi yang menarik bagi para wisatawan asing.

Pengelolaan kelembagaan paguyuban becak bestari dalam meningkatkan kualitas pelayanan wisatawan berbasis aktivitas bersenang-senang, memiliki aspek kebijakan khusus pada sektor pariwisata dan internal kelembagaan. Kelompok pendorong munculnya kebijakan pariwisata, yaitu berasal dari kelompok masyarakat, yaitu Paguyuban Becak Bestari kota Probolinggo. Kerangka kebijakan pengembangan pariwisata tergantung dari berbagai aspek filosofis masyarakat, yaitu ekonomi, sosial, lingkungan dan tujuan-tujuan politik (Ritchie dan Crouch, 2003). Pelayanan becak wisata berkembang bila didukung oleh pemerintah daerah, swasta dan masyarakat. Peran ketiga pihak tersebut untuk memperoleh pelayanan becak wisata yang memuaskan bagi para pelanggannya.

Kepuasan pelanggan terlihat dari sikap senang dan puas karena mereka merasakan adanya pelayanan yang efektif, efisien, berkualitas, bermutu, dan kompeten (Kholiq, 2019). Pemerintah daerah mempunyai tugas memberikan dukungan berupa kebijakan, regulasi dan aturan yang memberi kesempatan berkembangnya becak wisata. Selain itu, pemerintah daerah juga bisa mengerakkan sektor swasta dalam meningkatkan investasi di bidang pariwisata yang berkaitan becak wisata. Pelayanan prima dapat diwujudkan apabila mampu diselenggarakan dengan cara wirausaha. Mengutip dari konsep Reinventing Governace (Osborne \& Gabler, 1992) bahwa pelayanan publik prima dapat dilakukan dengan partisipatif, kompetitif, berorientasi pelanggan, antisipatif, dan terdesentraliasi. Becak wisata dapat memberikan pelayanan prima bila mampu memenuhi kriteria tersebut,terutama partisipatif dan berorientasi pelanggan sehingga pelayanan lebih mengutamakan kepuasan pelanggan dan tidak hanya sekedar keuntungan semata.

Paguyuban Becak Bestari kota Probolinggo memiliki peran strategis untuk menjalin kerjasama dengan berbagai pihak. Khususnya dalam melaksanakan program kegiatan yang direncanakan oleh Paguyuban Becak Bestari kota Probolinggo. Berbagai program kegiatan yang direncanakan oleh Paguyuban Becak Wisata, perlu untuk dievaluasi kembali. Dengan tujuan untuk meningkatkan pemberdayaan anggotanya. Juga memiliki peran strategis sebagai media promosi wisata Kota Probolinggo. Pemenuhan kebutuhan anggota masyarakat, akan semakin optimal dan berjalan linier seiring pengelolaan kelembagaan paguyuban yang semakin baik.

\section{Simpulan}

Pelayanan menjadi aspek penting dalam menjaga eksistensi moda transportasi becak wisata dan membangun kenangan positif wisatawan. SOP pelayanan becak wisata khusus wisatawan kapal pesiar sangat diperlukan. Kualitas pelayanan dalam revitalisasi fungsi kelembagaan harus diutamakan, seiring dengan tingkat kebutuhan dan perkembangan persepsi wisatawan terhadap moda transportasi becak wisata yang unik dan menjadi daya tarik. Menjadi sangat vital peranannya, khususnya dalam pelayanan kepada wisatawan kapal pesiar. Dengan harapan, akan terbangun persepsi positif wisatawan terhadap kota Probolinggo sebagai destinasi wisata kapal pesiar.

\section{Daftar Pustaka}

Azhari, Abdul Kholiq dan Abul Haris Suryo Negoro, 2019, Desentralisasi Dan Otonomi Daerah Di Negara Kesatuan Republik Indonesia, Malang: Intrans Publishing

Burton, Rosemary. 1995. Travel Geography, $2^{\text {nd }}$ Edition. London: Pitman Publishing.

Dinas Kebudayaan dan Pariwisata Kota Probolinggo. 2017. Jumlah Wisatawan Mancanegara melalui

Pelabuhan Tanjung Tembaga Kota Probolinggo Tahun 2014 - 2017. Probolinggo:

Dinas Kebudayaan dan Pariwisata Kota Probolinggo. 2018. Data Base Kepariwisataan Kota Probolinggo. Probolinggo

Fandeli, Chafid (Ed). 1995. Dasar-dasar Manajemen Kepariwisataan Alam. Liberty Offset. Yogjakarta

Gallimore, Max. 2011. From Here to Caprock. United States: Xlibris Coorporation. 
Gold, Seymour M. 1980. Recreation Planning and Design. New York: McGraw-Hill Book Company. Hee, Limin. 2017. Constructing Singapore Public Space. Springer Science + Bussiness Media Singapore. Kementerian Pariwisata. 2002. Kebijakan dan Strategi Pemasaran Wisata Nusantara. Jakarta: Kementerian Pariwisata RI.

Kementerian Pariwisata. 2017. Statistical Report on Visitors Arrival to Indonesia 2016. Jakarta: Deputy Asistant for Research and Development on Tourism Policy, Ministry of Tourism of Indonesia.

Kotler, Philip; Bowen, John; Makens, James. 1996. Marketing for Hospitality and Tourism. New Jersey: Prentice-Hall, Inc.

Miles, B. Mathew dan Michael Huberman. 1992. Analisis Data Kualitatif Buku Sumber Tentang Metodemetode Baru. Jakarta: UIP.

Middleton, Victor T.C. dan Hawkins, Rebecca. 1998. Sustainable Tourism: A Marketing Perspective. Oxford: Butterworth and Heinemann.

Mill, Robert Christie dan Morrison, Alastair M. 1992. The Tourism System: An Introductory Text, Second Edition. New Jersey: Prentice-Hall, Inc.

Osborne, David \& Ted Gaebler, Ted. 1992, Reinventing Government : Haw the Entrepreneurial Spirit is Transforming the Public Sector. Massachusetts. Addison-Wesly Publishing Company.

Parasuraman, A., Berryl, Leonard L, And Zeithhaml, Valerie A.1985. a Conceptual Model Of Service Quality and Its Implications For Future Research. Journal Of Marketing. Vol 49,pp. 41-50

Ritchie, J.R. Brent dan Crouch, Geoffrey. 2003. The Competitive Destination: A. Sustainable Tourism Perspective. Madrid: CABI Publishing. 